\title{
PENGARUH MODEL PEMBELAJARAN KOOPERATIF GROUP INVESTIGATION DENGAN ASESMEN OTENTIK TERHADAP PRESTASI BELAJAR DAN KONSEP DIRI SISWA
}

\author{
G.Ery Suhartawan, W. Santyasa, M. Kirna \\ Program Studi Teknologi Pembelajaran, Program Pascasarjana, \\ Universitas Pendidikan Ganesha, Singaraja, Indonesia. \\ Email: ery.suhartawan@pasca.undiksha.ac.id, \\ wayan.santyasa@pasca.undiksha.ac.id, made.kirna@pasca.undiksha.ac.id
}

\begin{abstract}
Abstrak
Penelitian ini bertujuanmenjelaskan perbedaan prestasi belajar dan konsep diri antara siswa yang belajar dengan model pembelajaran kooperatif Group Investigation dan asesmen otentik,model pembelajaran Group Investigation,dan model pembelajaran konvensional. Penelitian eksperimen semu ini dengan mengambil populasi 5 kelas siswa kelas VIII SMPNegeri 3 Kubu, Karangasem Tahun Pelajaran 2015/2016. Sampel ditentukan dengan teknik group random sampling. Berdasarkan hasil random, terpilih kelas VIIIE sebagai kelompok eksperimen menggunakan model pembelajaran kooperatif Group Investigation dengan asesmen otentik, kelas VIIIB menggunakan model pembelajaran kooperatifGroup Investigation, dan VIIID menggunakan model pembelajaran konvensional. Data prestasi belajar dikumpulkan dengan tes, sedangkan konsep diri dengan angket. Data dianalisis secara deskriptif dan analisis multivariat (MANCOVA).

Hasil penelitian menunjukkan bahwa 1) terdapat perbedaan signifikan prestasi belajar IPA dan konsep diri siswa antara siswa yang belajar dengan model pembelajaran kooperatif Group Investigation dengan asesmen otentik, model pembelajaran kooperatif Group Investigation, dan siswa yang belajar dengan model pembelajaran konvensional,; 2)terdapat perbedaan signifikan prestasi belajar IPA antara siswa yang belajar dengan menggunakan model pembelajaran kooperatif Group Investigationdan asesmen otentik, siswa yang belajar dengan model pembelajaranGroup Investigation dan siswa yang belajar dengan model pembelajaran konvensional,;3)terdapat perbedaan konsep diri antara kelompok siswa yang belajar dengan menggunakan model pembelajaran kooperatif Group Investigationdengan asesmen otentik dan siswa yang belajar dengan menggunakan model pembelajaran kooperatif Group Investigation, dan siswa yang belajar dengan model pembelajaran konvensional.Prestasi belajar IPA dan konsep diri siswa yang belajar dengan model pembelajaran kooperatif Group Investigationdan asesmen otentik lebih baik dibandingkan dengan kooperatif Group Investigationdan model pembelajaran konvensional
\end{abstract}

Kata Kunci : Model Pembelajaran Kooperatif Group Investigation, Asesmen otentik Pembelajaran Konvensional, Prestasi Belajar, Konsep Diri

\begin{abstract}
This study aims to explain the difference of learning achievement and self-concept among students learning with cooperative learning model of Group Investigation and authentic assessment, learning model of Group Investigation and conventional learning models. This quasi-experimental research by taking a population of 5 grade class VIII SMP Negeri 3 Kubu, Karangasem in the academic year 2015/2016. Sample group was determined by random sampling technique. Based on the results of random, VIIIE class selected as an experimental group using cooperative learning model of Group Investigation with authentic assessment, VIIIB class using cooperative learning model of Group Investigation, and VIIID using conventional learning models. Data collected by the learning achievement tests, while the self-concept questionnaire. Data were analyzed by descriptive and multivariate analysis (MANCOVA).
\end{abstract}


The results showed that 1 ) there is a significant difference in learning achievement in science and the concept of self-esteem among students learning with cooperative learning model of Group Investigation with authentic assessment, cooperative learning model of Group Investigation, and the students who studied with conventional learning model,; 2) there is a significant difference in learning achievement between students learning science by using cooperative learning model of Group Investigation and authentic assessment, students who studied with Group Investigation learning model and student learning with conventional learning model ; 3) there is a difference between groups of self-concept students learn by using cooperative learning model of Group Investigation with authentic assessment and student learning using cooperative learning model of Group Investigation, and the students who studied with conventional learning models. Science learning achievement and self-concept students learn cooperative learning model of Group Investigation and authentic assessment is better than the cooperative learning model of Group Investigation and conventional

Keywords: cooperative learning model group investigation, assessment authentic, conventional learning, learning achievement, self concept

PENDAHULUAN

Pendidikan memegang peranan penting dalam peningkatan kualitas sumber daya manusia yang mampu menghadapi tantangan zaman. Agar tercipta sumber daya manusia yang kompetitif dan memiliki daya saing, diperlukan peningkatan kualitas pendidikan yang berkesinambungan. Untuk menjawab segala tantangan jaman, maka harus ada perubahan paradigma dalam pendidikan. Perubahan paradigma pendidikan yaitu dari teacher centered menjadi student centered, dari satu arah menjadi interaktif, dari isolasi menuju lingkungan jejaring, dari pasif menuju aktif menyelidiki, dari abstrak menuju konteks dunia nyata, dari pribadi menuju pembelajaran berbasis tim, dari hubungan satu arah menuju kooperatif, dari penyampaian pengetahuan menuju pertukaran pengetahuan. Perubahan paradigma pendidikan ini diharapkan akan dapat meningkatkan mutu pendidikan di Indonesia.

Reformasi pendidikan berarti perubahan yang bermakna dan terencana dalam bidang pendidikan dengan mengikis habis berbagai kekurangan yang ada, serta memperkenalkan secara berencana berbagai nilai dan sikap bermutu dengan utuh dan terpadu dalam dinamika pendidikan yang ada. Reformasi pendidikan harus dilakukan secara bertahap, terencana serta dievaluasi secara berkala (Haikal, 2002). Terdapat beberapa inovasi 
yang dilakukan oleh pemerintah selama beberapa dekade terakhir ini terkait upaya reformasi pendidikan. Salah satunya adalah pembaharuan kurikulum. Menurut Suparno dkk.(2002), seiring perkembangan masyarakat yang ditandai oleh perkembangan teknologi informasi dan komunikasi, tuntutan adanya reformasi pendidikan khususnya pembaruan kurikulum yang sesuai dengan jamannya menjadi relevan. Menjawab tuntutan tersebut, pemerintah telah menyempurnakan Kurikulum 1994 menjadi Kurikulum 2004 atau Kurikulum Berbasis Kompetensi (KBK). Kemudian disempurnakan dengan diterapkannya Kurikulum Tingkat Satuan Pendidikan (KTSP). Bahkan sekarang semakin sempurna dengan diterapkannya Kurikulum 2013.

Darmawan (2014) menyatakan kualitas pendidikan di Indonesia masih jauh dari harapan kita. Di Indonesia, umumnya sistem pengajaran IPA yang dilakukan oleh guru belum menjadikan keberagaman kemampuan siswa sebagai pertimbangan untuk mengelola proses pembelajaran, serta belum memberikan kesempatan yang cukup pada siswa untuk mengambil peran dalam proses pembelajaran penyebab kualitas pendidikan IPA di sekolah masih rendah.

Rendahnya kualitas pendidikan IPA di sekolah-sekolah disebabkan pelaksanaan proses pembelajaran IPA di sekolah masih bersifat konvensional, pembelajaran hanya mengutamakan produk, dan hanya sedikit yang mengarah pada proses menemukan pengetahuan tersebut. Pelaksanaan proses pembelajaran yang tidak seimbang antara proses dan produk, menyebabkan siswa tidak mampu menumbuhkan dan mengembangkan sikap ilmiah yang ada di dalam dirinya. Hal ini menyebabkan pengetahuan yang didapatkan oleh siswa hanya berupa teori yang dihapal sehingga pengetahuan tersebut menjadi tidak bermakna dan mudah dilupakan (Astawa, 2015).

Model pembelajaran kooperatif merupakan salah satu model pembelajaran yang dilandasi pandangan kontruktivisme. Pandangan kontruktivisme menuntut siswa membangun pengetahuannya sendiri (Trianto,2007). Menurut teori kontruktivisme, guru hanya sebagai fasilitator sehingga siswa mampu 
mengkonstruksi pengetahuannya sendiri dengan optimal dan biasanya diwujudkan melalui kerja kelompok. Sesuai dengan karakteristik pembelajaran kooperatif, siswa belajar dalam kelompok yang sifatnya heterogen. Pembelajaran kooperatif lebih mementingkan kerja sama siswa dalam kelompok untuk mencapai tujuan pembelajaran. Keberhasilan dari masing-masing anggota kelompok menunjang keberhasilan kelompok. Investigasi Kelompok (Group Investigation) yang disingkat (GI) merupakan salah satu tipe pembelajaran kooperatif yang paling kompleks. Siswa dilibatkan dalam perencanaan baik topik yang dipelajari dan bagaimana jalannya penyelidikan mereka. Model ini mengajarkan kepada siswa dalam komunikasi kelompok dan proses kelompok yang baik. Model GI dikembangkan untuk membangun semua aspek kemampuan.

Di sisi lain, Syamsir (2003), menyatakan bahwa kegagalan pendidikan di Indonesia selama ini, antara lain disebabkan oleh ketidaktepatan dalam pelaksanaan penilaian yang dilakukan dalam mata pelajaran yang bersangkutan di sekolah-sekolah. Proses penilaian pembelajaran IPA sementara ini hanya difokuskan pada ranah kognitif saja (Busnawir \& Suhaena, 2006; Maryam, 2006; Rapi, 2005). Pernyataan tersebut didukung oleh hasil penelitian Suastra et.al. (2006), yang menunjukkan bahwa penilaian yang digunakan untuk menilai prestasi belajar siswa $100 \%$ hanya mengukur aspek kognitif yakni menggunakan kuis, ulangan akhir pokok bahasan, ulangan umum, dan tugas rumah tanpa menilai unjuk kerja siswa.

Terkait dengan penilaian dalam pembelajaran IPA, selama ini penilaian kinerja siswa dinilai dengan tes tulis sehingga penilaian yang dilakukan tidak valid karena tidak mampu mengukur apa yang seharusnya dapat diukur. Kinerja perlu dinilai pada saat kegiatannya sedang berlangsung (Rustaman, 2006; Suastra, 2007). Penilaian kinerja sangat penting dalam pembelajaran IPA, salah satu ciri IPA adalah adanya perpaduan antara eksperimen dengan teori (Suastra, 2006). Pada saat melakukan ekperimen, kinerja siswa perlu dinilai. Terlebih lagi dengan pemberlakuan Kurikulum 2013 membawa konsekuensi pada perubahan sistem penilaian dari yang didominasi oleh 
paper and pencil test menuju pada penilaian yang otentik (authentic assessment), yaitu berupa tugastugas kehidupan yang sesungguhnya.

Dalam meningkatkan prestasi belajar, kesulitan yang dirasakan guru-guru IPA adalah bagaimana cara menanamkan konsep diri dan kebiasaan belajar siswa yang baik agar dapat meningkatkan prestasi belajar. Pemahaman tentang konsep diri (self concept) penting untuk ditanamkan pada diri siswa. Konsep diri adalah pikiran atau persepsi seseorang tentang dirinya sendiri. Cooley (2004), menyebutnya sebagai the looking glass self, konsep ini berbicara tentang bagaimana seseorang mengevaluasi dirinya sendiri atas dasar sikap dan perilaku orang lain. Model pembelajaran inovatif yang dikemas dalam proses pembelajaran merupakan hal yang positif terhadap konsep diri siswa dalam mengikuti proses pembelajaran dan keberhasilan dalam belajar. Konsep diri akan memberikan kerangka acuan yang mempengaruhi manajemen diri terhadap situasi dan terhadap orang lain. Konsep diri ada yang sifatnya positif dan negatif. Individu yang memiliki konsep diri negatif akan cenderung mempunyai kepribadian yang labil dan bersifat pesimistis terhadap kehidupan (Astawa, 2015).

Paparan situasi tersebut mengindikasikan perlunya diterapkan model pembelajaran dan penilaian yang sesuai dengan paradigma konstruktivisme sehingga dapat meningkatkan prestasi dan konsep diri siswa. Becker dan Maunsaiyat (2004) menyatakan bahwa salah satu model pembelajaran yang berlandaskan konstruktivisme adalah model pembelajaran kooperatif. Model pembelajaran kooperatif merupakan sebuah model yang menyediakan peluang kepada siswa bekerja sama untuk memperoleh tujuan bersama dalam kelompokkelompok kecil. Pada model pembelajaran kooperatif, sinergi yang muncul dalam kerja kooperatif menghasilkan motivasi yang lebih dari kerja individualistik dalam lingkungan belajar kompetitif.

Model pembelajaran kooperatif dikembangkan menjadi beberapa tipe, salah satunya adalah Group Investigation (GI). Model pembelajaran kooperatif Group Investigation merupakan model pembelajaran kooperatif yang mengkombinasikan dinamika proses 
demokrasi dengan proses inkuiri akademik. Pebelajar memilih sendiri topik yang akan dipelajari, dan kelompok merumuskan penyelidikan dan menyepakati pembagian kerja untuk menangani konsep-konsep penyelidikan yang telah dirumuskan. Konsep penting dalam model pembelajaran kooperatif $\mathrm{Gl}$ yang bersifat humanis ini adalah: menghindarkan evaluasi menggunakan tes, learning by doing, membangun motivasi intriksik, mengutamakan pilihan pebelajar, memperlakukan pebelajar sebagai orang bertanggung jawab, pertanyaan-pertanyaan terbuka, mendorong rasa saling menghormati dan saling membantu, dan membangun konsep diri yang positif (Santyasa, 2012).

Berdasarkan uraian di atas, model pembelajaran kooperatif group investigation dengan asesmen otentik sangat penting untuk diselidiki pengaruhnya terhadap prestasi belajar IPA dan konsep diri siswa dan keterampilan berfikir kritis siswa. Penelitian ini pada hakekatnya bertujuan Menjelaskan perbedaan prestasi belajar dan konsep diri antara siswa yang belajar dengan menggunakan model pembelajaran kooperatif Group Investigation dengan asesmen otentik, siswa yang belajar dengan menggunakan model Group Investigation, dan model pembelajaran konvensional, setelah perlakuan dikontrol dengan kovariabel prestasi belajar dan konsep diri awal.

\section{METODE PENELITIAN}

Penelitian ini merupakan penelitian kuasi eksperimen. Pada penelitian ini dibagi menjadi 3 kelompok siswa. Kelompok siswa yang menggunakan model pembelajaran kooperatif Group Investigation dengan asesmen otentik, kelompok siswa yang menggunakan model pembelajaran kooperatif Group Investigation, dan kelompok siswa yang menggunakan model pembelajaran konvensional dalam jangka waktu tertentu, kemudian ketiga kelompok dikenai pengukuran yang sama. Rancangan penelitian yang digunakan adalah desain penelitian pretest-posttest control group design.

Populasi dalam penelitian ini adalah siswa kelas VIII yang ada di SMP Negeri 3 Kubu Kabupaten Karangasem berjumlah 139 siswa yang terbagi dalam 5 kelas dengan kemampuan yang merata, untuk 
menentukan sampel penelitian digunakan teknik group random sampling (random kelas). Berdasarkan hasil random diperoleh kelas VIIIE sebagai kelompok yang menggunakan model pembelajaran kooperatif Group Investigation (GI) dengan otentik asesmen, Kelas VIII B kelompok yang menggunakan model pembelajaran kooperatif Group Investigation (GI) dan kelas VIII D kelompok yang menggunakan model pembelajaran konvensional.

Yang merupakan variabel dalam penelitian ini dapat didefinisikan sebagai berikut.

1) Variabel bebas (independent
variable) merupakan variabel
yang menyebabkan atau mempengaruhi, yaitu faktor-faktor yang diukur, dimanipulasi atau dipilih oleh peneliti untuk menentukan hubungan antara fenomena yang diobservasi atau diamati. Variabel bebas dalam penelitian ini adalah Model Pembelajaran yang terdiri dari tiga dimensi yaitu: 1) Model pembelajaran kooperatif Group Investigation dengan asesmen otentik, 2) Model pembelajaran kooperatif Group Investigation ; dan

3)

Pembelajaran konvensional.

2) Varibel terikat (dependent variable), merupakan faktor-faktor yang diobservasi dan diukur untuk menentukan adanya pengaruh variabel bebas, yaitu faktor yang muncul, atau tidak muncul, atau berubah sesuai dengan yang diperkenalkan oleh peneliti. Pada penelitian ini variabel terikat yang digunakan terdiri dari dua dimensi yaitu: 1) prestasi belajar IPA; dan 2) dan konsep diri.

3. Kovariabel merupakan variabel yang mengendalikan secara statistik terhadap variabel lain dalam penelitian. Pada penelitian ini, yang digunakan sebagai kovariabel adalah data pretasi belajar awal dan konsep diri awal siswa.

Untuk mengumpulkan data yang diperlukan menggunakan test dan angket. Tes digunakan untuk mendapatkan data berupa prestasi belajar IPA. Tes yang dimaksud adalah tes IPA yang berbentuk obyektif pilihan ganda dengan dikembangkan berdasarkan ranah kognitif taksonomi Bloom meliputi C1, C2 dan C3, dan angket digunakan untuk memperoleh data berupa 
Konsep diri. Angket yang dimaksud adalah berupa kuesioner yang dijawab siswa yang sesuai dengan keadaan dirinya sendiri. Dengan jumlah 45 pertanyaan yang digunakan dalam uji coba, dari analisis hasil uji coba didapat 5 pertanyaan yang gugur, jadi butir soal yang digunakan dalam penelitian berjumlah 40 soal dengan skor 1-5.

Teknik analisis yang digunakan adalah MANCOVA (Multivariat Analysis of Covarian) satu jalur yang melibatkan satu variabel bebas dan dua variabel terikat. Asumsi dasar yang harus terpenuhi dalam Mancova adalah 1) distribusi data harus normal yang dilakukan dengan uji normalitas data, 2) setiap kelompok hendaknya memiliki varians yang sama pula, dilakukan dengan uji homogenitas data, 3) pengambilan sampel dilakukan secara random, dan 4) tidak terdapat masalah multikolineritas.

Dalam penelitian ini dilakukan 3 uji hipotesis diantaranya : hipotesis I menyatakan terdapat perbedaan prestasi belajar dan konsep diri antara siswa yang belajar dengan menggunakan model pembelajaran kooperatif Group Investigation dengan asesmen otentik, siswa yang belajar dengan menggunakan model Group
Investigation,

dan

model

pembelajaran konvensional, setelah perlakuan dikontrol dengan kovariabel prestasi belajar dan konsep diri awal, hipotesis II menyatakan Terdapat perbedaan prestasi belajar antara siswa yang belajar dengan menggunakan model pembelajaran kooperatif Group Investigation dengan asesmen otentik, siswa yang belajar dengan menggunakan model Group Investigation, dan model pembelajaran konvensional, setelah perlakuan dikontrol dengan kovariabel prestasi belajar dan konsep diri awal, dan hipotesis III terdapat perbedaan konsep diri antara siswa yang belajar dengan menggunakan model pembelajaran kooperatif Group Investigation dengan asesmen otentik, siswa yang belajar dengan menggunakan model Group Investigation, dan model pembelajaran konvensional, setelah perlakuan dikontrol dengan kovariabel prestasi belajar dan konsep diri awal. Program yang digunakan dalam mengolah data adalah SPSS-PC 17.0 for Windows. Pengujian hipotesis dilakukan pada taraf signifikansi $5 \%$.

HASIL PENELITIAN DAN

PEMBAHASAN 
Penelitian ini memaparkan dua hal, meliputi: (1) deskripsi umum hasil penelitian, (2) analisis data serta pengujian hipotesis.

Deskripsi umum hasil penelitian tentang karakteristik dari masingmasing variabel penelitian. Deskripsi prestasi belajar IPA dan konsep diri siswa sesudah perlakuan diberikan mencakup distribusi frekuensi, nilai rata-rata (mean), dan standar deviasi (SD).

Rata-rata prestasi belajar siswa yang belajar dengan menerapkan model pembelajaran kooperatif GI dengan asesmen otentik adalah 77,00. Hal ini menunjukkan bahwa prestasi belajar IPA siswa yang belajar dengan menerapkan model pembelajaran kooperatif $\mathrm{Gl}$ dengan asesmen otentik di SMP Negeri 3 Kubu sangat tinggi $\left(\bar{X}_{\geq} 75,00\right)$, ratarata prestasi belajar siswa yang belajar dengan menerapkan model pembelajaran kooperatif $\mathrm{Gl}$ adalah 65,85. Hal ini menunjukkan bahwa prestasi belajar IPA siswa yang belajar dengan menerapkan model pembelajaran kooperatif GI di SMP Negeri 3 Kubu berkategori tinggi $(58,33 \leq \bar{X}<75,00)$, dan Rata-rata prestasi belajar siswa yang belajar dengan menerapkan model pembelajaran konvensional adalah 62,57. Hal ini menunjukkan bahwa prestasi belajar IPA siswa yang belajar dengan menerapkan model pembelajaran kooperatif $\mathrm{Gl}$ di SMP Negeri 3 Kubu berkategori tinggi $(58,33 \leq \bar{X}<75,00)$.

Rata-rata konsep diri siswa dengan menerapkan model pembelajaran kooperatif $\mathrm{Gl}$ dengan asesmen otentik adalah 71,85 . Hal ini menunjukkan bahwa konsep diri siswa yang belajar dengan menerapkan model pembelajaran kooperatif GI dengan asesmen otentik di SMP Negeri 3 Kubu berkategori tinggi

$(70,00 \leq \bar{X}<90,00)$, rata-rata konsep diri siswa dengan menerapkan model pembelajaran kooperatif $\mathrm{Gl}$ adalah 68,28 . Hal ini menunjukkan bahwa konsep diri siswa yang belajar dengan menerapkan model pembelajaran kooperatif GI di SMP Negeri 3 Kubu berkategori sedang $(50,00 \leq \bar{X}<70,00)$, dan rata-rata konsep diri siswa dengan menerapkan model pembelajaran konvensional adalah 66,03. Hal ini menunjukkan bahwa konsep diri siswa yang belajar dengan 
menerapkan model pembelajaran konvensional di SMP Negeri 3 Kubu berkategori sedang $(50,00 \leq \bar{X}<$ 70,00).

Analisis data penelitian dilakukan setelah semua uji asumsi terpenuhi. Uji asumsi yang digunakan untuk analisis diantaranya: uji normalitas, uji homogenitas data, uji homogenitas matriks varian/covarians, uji linieritas, dan uji kolinearitas antar variabel dependen .

Hasil pengujian normalitas berdasarkan nilai-nilai statistik Kolmogorov-Smirnov Test menunjukkan angka signifikansi lebih besar dari 0,05 baik pada kelompok siswa yang belajar dengan model kooperatif group investigation dngan asesmen otentik, model pembelajaran kooperati group investigation, dan kelompok siswa yang belajar dengan model konvensional. Secara keseluruhan sebaran data prestasi belajar IPA dan konsep diri siswa berdistribusi normal.

Uji homogenitas dimaksudkan untuk memperlihatkan bahwa dua atau lebih kelompok sampel data berasal dari populasi yang memiliki varian yang sama. Uji homogenitas varian antarkelompok ini dapat dilakukan dengan menggunakan
Levene's test of equality of error variance. Menunjukkan bahwa taraf signifikansi prestasi belajar IPA pada based on mean yaitu 1,017 dengan signifikansi 0,366 bearti signifikasinya lebih besar dari 0,05 (sig > 0,05). Dapat disimpulkan bahwa $\mathrm{H}_{0}$ diterima dan $\mathrm{H}_{1}$ ditolak. Artinya, semua kelompok data memiliki varians yang sama atau homogen pada prestasi belajar. Pada konsep diri siswa pada based on mean yaitu 2,062 dengan signifikansi 0,134 bearti signifikansinya lebih besar dari 0,05 (sig > 0,05). Dapat disimpulkan bahwa $\mathrm{H}_{0}$ diterima dan $\mathrm{H}_{1}$ ditolak. Artinya, semua kelompok data juga memiliki varians yang sama atau homogen pada konsep diri siswa.

Uji homogenitas matriks varians-kovarians sebagai syarat sebelum melakukan analisis MANCOVA dilakukan dengan menggunakan uji Box's Test of Equality of Covariance Matrices. Hasil uji matriks varians-kovarians pada data prestasi belajar IPA dan konsep diri siswa menunjukkan angka Box's $M$ sebesar 11,848 , nilai $F$ sebesar 1,904 dan angka signifikansi sebesar 0,076 . Mengingat angka signifikansi lebih besar dari 0,05 maka dapat disimpulkan bahwa matriks varians- 
kovarians antarvariabel prestasi belajar IPA dan konsep diri siswa adalah homogen. Hasil pengujian linieritas dengan memperhatikan, hasil analisis prestasi belajar IPA pada tabel Anova di atas diperoleh nilai $F$ Liniearity besarnya 17,051 dengan nilai signifikansi 0,001. Hasil signifikansi yang diperoleh lebih kecil dari signifikansi yang ditetapkan sebesar $\alpha=0,05$, ini berarti $\mathrm{H}_{0}$ ditolak dan $\mathrm{H}_{1}$ diterima. Artinya, koefisien arah regresi adalah signifikan.

Hasil pengujian linieritas dengan memperhatikan hasil analisis prestasi belajar IPA pada tabel Anova di atas diperoleh nilai $F$ Liniearity besarnya 17,051 dengan nilai signifikansi 0,001 . Hasil signifikansi yang diperoleh lebih kecil dari signifikansi yang ditetapkan sebesar $\alpha$ $=0,05$, ini berarti $\mathrm{H}_{0}$ ditolak dan $\mathrm{H}_{1}$ diterima. Artinya, koefisien arah regresi adalah signifikan.

Pengujian linieritas dilakukan dengan menguji $\mathrm{H}_{0}$ yang menyatakan bentuk regresi linier, melawan $\mathrm{H}_{1}$ yang menyatakan bentuk regresi tidak linier. Pada tabel di atas dengan memperhatikan nilai $F$ Deviation from Linearity sebesar 1,526 dan nilai signifikansi sebesar 0,171. Signifikansi yang diperoleh lebih besar dari signifikansi $\alpha=0,05$. Dengan demikian $\mathrm{H}_{0}$ diterima dan $\mathrm{H}_{1}$ ditolak. Artinya, bentuk regresi prestasi belajar IPA adalah linier. Pada hasil analisis konsep diri siswa pada tabel Anova di atas diperoleh nilai $F$ Liniearity besarnya 31,595 dengan nilai signifikansi 0,001 . Hasil signifikansi yang diperoleh lebih kecil dari signifikansi yang ditetapkan sebesar $\alpha=0,05$, ini berarti $\mathrm{H}_{0}$ ditolak dan $\mathrm{H}_{1}$ diterima. Artinya, koefisien arah regresi adalah signifikan.

Pengujian linieritas dilakukan dengan menguji $\mathrm{H}_{0}$ yang menyatakan bahwa bentuk regresi linier, melawan $\mathrm{H}_{1}$ yang menyatakan bentuk regresi tidak linier. Pada tabel di atas dengan memperhatikan nilai F Deviation from Linearity sebesar 1,496 dan nilai signifikansi sebesar 0,124 . Signifikansi yang diperoleh lebih besar dari signifikansi $\alpha=0,05$. Dengan demikian $\mathrm{H}_{0}$ diterima dan $\mathrm{H}_{1}$ ditolak. Artinya, bentuk regresi konsep diri siswa adalah linier.

Pengujian kolinieritas dengan menggunakan kaidah harga korelasi product moment yang terbaik jika koefisien korelasi bergerak diantara $r$ $<0,6$

diperoleh koefisien korelasi pearson product moment antara variabel 
prestasi belajar IPA dengan konsep diri siswa sebesar 0,192. Menurut Arikunto (2005) MANCOVA akan memberikan interpretasi yang terbaik jika terdapat korelasi yang tidak begitu besar dengan koefisien korelasi bergerak di antara $r<0,6$. Selain itu, Arikunto (2005) juga mengungkapkan bahwa penggunaan MANCOVA yang memiliki korelasi yang tinggi pada variabel dependen sangat tidak efektif. Dari hasil tersebut dapat disimpulkan bahwa uji MANCOVA dapat dilanjutkan.

Secara umum setelah melalui uji prasyarat, data prestasi belajar dan konsep diri siswa dalam penelitian memiliki sebaran data normal, varians homogen, matriks varians-kovarians homogen, bentuk regresi prestasi belajar dan konsep diri siswa yang linier, serta kolinearitas antarvariabel dapat ditoleransi sehingga analisis MANCOVA untuk pengujian hipotesis dapat dilanjutkan.

Analisis statistik yang dilakukan berikutnya adalah analisis untuk menguji hipotesis penelitian. Pengujian hipotesis pertama menggunakan analisis multivariat

untuk mengetahui pengaruh masing-masing variabel independen (model pembelajaran dengan tiga dimensi yakni $\mathrm{Gl}+\mathrm{OA}, \quad \mathrm{Gl}$ dan konvensional) terhadap variabel dependen (prestasi belajar IPA dan konsep diri siswa) secara bersamasama.

Pengaruh model belajar ditemukan bahwa nilai-nilai statistik Pillai's Trace dengan $\mathrm{F}=19,631$ dan angka signifikansi $0,001, W^{\prime}$ ilks' Lambda dengan $\mathrm{F}=27,756$ dan angka signifikansi 0,001 , Hotelling's Trace dengan $F=36,853$ dan angka signifkansi 0,001, dan Roy's Largest Root dengan $\mathrm{F}=75,299$ dan angka signifikansi masing-masing 0,001. Angka signifikansinya lebih kecil dari 0,05 . Hal ini dijadikan dasar dalam pengambilan keputusan. Hipotesis nol yang menyatakan "tidak ada pengaruh model belajar prestasi belajar IPA dan konsep diri siswa secara bersama-sama" ditolak. Jadi secara bersama-sama prestasi belajar IPA dan konsep diri siswa secara signifikan $(P<0,05)$ dipengaruhi oleh kovariat model belajar.

Simpulan yang dapat ditarik adalah terdapat perbedaan prestasi belajar IPA dan konsep diri siswa yang signifikan antara kelompok siswa yang belajar dengan menerapkan model pembelajaran kooperatif Gl dengan asesmen 
otentik, model pembelajaran kooperatif Gl dengan siswa yang belajar dengan menerapkan model pembelajaran konvensional.

Hipotesis kedua dan hipotesis ketiga yang diajukan adalah dianalisis dengan MANCOVA. Hipotesis kedua dapat diuji berdasarkan Tabel Tests of Between-Subjects Effects dapat diketahui nilai statistik $F=35,115$ dengan angka signifikansi 0,001. Angka signifikansi ini lebih kecil dari 0,05 , sehingga dapat diambil keputusan untuk $\mathrm{H}_{0}$ (2) sebagai berikut. Setelah perlakuan dikontrol dengan kovariabel prestasi belajar dan konsep diri awal. terdapat perbedaan nilai rata-rata prestasi belajar IPA antara kelompok siswa yang belajar dengan menggunakan model pembelajaran kooperatif Group Investigation dengan asesmen otentik terhadap kelompok siswa yang belajar dengan menggunakan model pembelajaran Group Investigation dan kelompok siswa yang belajar dengan model pembelajaran konvensional", diterima. Jadi, terdapat pengaruh signifikan $(p<0,05)$ variabel modelmodel pembelajaran terhadap prestasi belajar IPA, hipotesis ketiga menggunakan analisis MANCOVA. Rata-rata konsep diri siswa kelompok siswa yang belajar dengan menerapkan model pembelajaran kooperatif GI dengan asesmen otentik sebesar $\mathrm{M}=71,85$ dengan $\mathrm{SD}=4,248$ lebih besar dari rata-rata kelompok siswa yang belajar dengan menerapkan model pembelajaran kooperatif $\mathrm{Gl}$ sebesar $\mathrm{M}=68,28$ dengan $\mathrm{SD}=3,173$ dan lebih besar dari rata-rata kelompok siswa yang belajar dengan menerapkan model pembelajaran konvensional sebesar $M=66,03$ dengan $S D=3,338$.

Hasil uji tindak lanjut menggunakan uji LSD menemukan terdapat perbedaan nilai rata-rata $\mathrm{PB}$ adalah $\quad \Delta \mu(P B)=\left(\mu_{G I+O A}-\right)=14,143$ dengan $\mathrm{SD}=1,759$ dan signifikansi $0,001, \quad \Delta \mu(P B)=\left(\mu_{G I+O A}-\mu_{G I}\right)=$ 10,857 dengan $S D=1,759$ dan signifikansi 0,001 , nilai $\Delta \mu(P B)=$ $\left(\mu_{G I}-\mu_{K O N}\right)=3,286$ dengan $\quad \mathrm{SD}=$ 1,759 , lebih besar dari LSD $(\mathrm{PB})=$ 3,26 . Jadi nilai rata-rata prestasi belajar IPA antara kelompok siswa yang belajar dengan menggunakan model pembelajaran kooperatif Group Investigation dengan asesmen otentik secara statistik lebih besar dari kelompok siswa yang belajar dengan menggunakan model pembelajaran Group Investigation dan kelompok 
siswa yang belajar dengan model pembelajaran konvensional.

Perbedaan nilai rata-rata konsep diri $(\mathrm{KD})$ adalah $\Delta \mu(K D)=$ $\left(\mu_{G I+O A}-\mu_{K O N}\right)=6,036$ dengan $\mathrm{SD}=$ 0,991 , nilai $\Delta \mu(K D)=\left(\mu_{G I+O A}-\mu_{G I}\right)=$ 3,643 dengan $S D=0,991$ dan signifikansi $\quad 0,001$, nilai $\quad \Delta \mu(K D)=$ $\left(\mu_{G I}-\mu_{K O N}\right)=2,393$ dengan $\mathrm{SD}=$ 0,991 , nilai rata-rata lebih besar dari $\operatorname{LSD}(K D)=1,57$. Jadi nilai rata-rata konsep diri siswa antara kelompok siswa yang belajar dengan menggunakan model pembelajaran kooperatif Group Investigationdengan asesmen otentik secara statistik lebih besar dari kelompok siswa yang belajar dengan menggunakan model pembelajaran Group Investigation dan kelompok siswa yang belajar dengan model pembelajaran konvensional. Prestasi belajar dan konsep diri dipengaruhi oleh berbagai faktor, di antaranya adalah model pembelajaran yang diterapkan. Oleh karena itu, guru diharapkan mampu memilih model pembelajaran secara selektif agar cocok dengan karakteristik materi atau pokok bahasan yang diajarkan sehingga tujuan pembelajaran yang ditetapkan dapat tercapai meliputi aspek kognitif, afektif serta psikomotornya.
Perlu disadari bahwa dalam pemilihan model pembelajaran, tidak semua pokok bahasan dalam bidang IPA dapat diajarkan dengan model pembelajaran yang sama karena setiap pokok bahasan memiliki karakteristik tersendiri, terutama kaitannya dengan penanaman konsep diri siswa dalam upaya pencapaian hasil belajar yang baik. Pemilihan model pembelajaran yang tepat untuk suatu pokok bahasan tertentu mampu meningkatkan prestasi belajar dan konsep diri siswa. Model pembelajaran kooperatif Group Investigation dengan asesmen otentik merupakan model pembelajaran yang dapat diterapkan guru dalam proses pembelajaran IPA.Secara empiris dalam penelitian menunjukkan bahwa terdapat perbedaan prestasi belajar dan konsep diri siswa yang belajar menggunakan model pembelajaran kooperatif Group Investigation dengan asesmen otentik, siswa yang belajar dengan model pembelajaran kooperatif Group Investigation dengan siswa yang belajar menggunakan model pembelajaran konvensional.

Berdasarkan hasil penelitian yang diperoleh dapat digambarkan bahwa, sangat diperlukan bimbingan guru dalam memilih fitur yang relevan 
dan pemberian permasalahan yang rial berkaitan dengan dunia pebelajar serta memberikan kesempatan kepada siswa untuk tahu dan terlibat secara aktif dalam menemukan konsep dari ide-ide mereka berdasarkan fakta-fakta yang dilihat dari lingkungan.

Model pembelajaran kooperatif menuntun siswa untuk aktif dalam mencari dan menemukan berbagai sumber informasi, menyelidiki dan membuktikan sendiri berbagai konsep yang dipelajari, menyimpulkan hasil suatu percobaan, dan menemukan serta memecahkan permasalahan yang terkait dengan konsep yang sedang dipelajari oleh siswa. Namun Kemasan belajar demokratis diakomodasi oleh model pembelajaran kooperatif Group Investigation.Pada tahap penyelidikan siswa menggunakan seluruh indera yang mereka miliki untuk berinvestigasi di dalam kelompok menemukan solusi dari permasalahan yang mereka hadapi. Jika proses penemuan mereka lakukan sendiri maka konsep yang mereka dapatkan akan tersimpan dengan baik di dalam pemikiran mereka (Ausebel et al., 1992). Proses investigasi ini memberikan keterlibatan siswa secara total dalam proses pembelajaran, sehingga siswa termotivasi untuk belajar. Keterlibatan ini akan membentuk konsep diri akademis siswa secara langsung untuk memaksimalkan potensi akademis siswa secara langsung. Tahap presentasi dan evaluasi siswa akan membentuk konsep diri kejujuran, kesetabilan emosi, dan konsep diri hubungan sosial. Hal ini erat kaitannya dengan pola pembelajaran yang demokratis. Dalam proses diskusi dan tanya jawab sangat penting sekali konsep diri siswa dalam menjaga emosi dan menjaga hubungan sosial dengan rekan-rekan diskusinya. Proses penyampaian pendapat dan penolakan pendapat harus dihargai dengan baik, karena pada dasarnya setiap pendapat tidak ada yang salah. Model pembelajaran kooperatif Group Investigation membina siswa untuk berdiskusi dengan baik, menghargai pendapat dengan baik, dan menajaga kesetabilan emosi siswa saat berdiskusi.

SIMPULAN DAN SARAN 
Berdasarkan atas hasil penelitian dan pembahasan di atas dapat dikemukakan kesimpulan sebagai berikut:

1) Setelah perlakuan dikontrol dengan kovariabel prestasi belajar dan konsep diri awal, terdapat perbedaan prestasi belajar dan konsep diri antara siswa yang belajar dengan menggunakan model pembelajaran kooperatif Group Investigation dengan asesmen otentik, siswa yang belajar dengan menggunakan model Group Investigation, dan model pembelajaran konvensional. Prestasi belajar dan konsep diri siswa yang belajar dengan menggunakan model pembelajaran kooperatif Group Investigation dengan asesmen otentik lebih baik dibandingkan dengan siswa yang belajar dengan menggunakan model pembelajaran kooperatif Group Investigation dan siswa yang belajar dengan model pembelajaran konvensional.

2) Setelah perlakuan dikontrol dengan kovariabel prestasi belajar dan konsep diri awal terdapat perbedaan prestasi belajar antara siswa yang belajar dengan menggunakan model pembelajaran kooperatif Group Investigation dengan asesmen otentik, siswa yang belajar dengan menggunakan model

Group Investigation, dan model pembelajaran konvensional. Prestasi belajar yang belajar dengan menggunakan model pembelajaran kooperatif Group Investigation dengan asesmen otentik lebih baik dibandingkan dengan siswa yang belajar dengan menggunakan model pembelajaran kooperatif Group Investigation dan siswa yang belajar dengan model pembelajaran konvensional.

3) Setelah perlakuan dikontrol dengan kovariabel prestasi belajar dan konsep diri awal, terdapat perbedaan konsep diri antara kelompok siswa yang belajar dengan menggunakan model pembelajaran kooperatif Group Investigation dengan asesmen otentik terhadap kelompok siswa yang belajar dengan menggunakan model pembelajaran kooperatif Group Investigation dan kelompok siswa yang belajar dengan model pembelajaran konvensional. Konsep diri siswa yang belajar dengan menggunakan model pembelajaran kooperatif Group Investigation dengan asesmen otentik lebih baik dibandingkan dengan siswa yang belajar dengan menggunakan model pembelajaran kooperatif Group 
Investigation dan siswa yang belajar dengan model pembelajaran konvensional.

Berdasarkan hasil penelitian diperoleh bahwa model pembelajaran kooperatif Group Investigation dengan asesmen otentik efektif digunakan untuk meningkatkan prestasi belajar dan konsep diri siswa, maka dalam proses pembelajaran dengan menggunakan model pembelajaran kooperatif Group Investigation dengan asesmen otentik dapat disarankan beberapa hal:

1) Dalam implementasi model pembelajaran kooperatif Group Investigation dengan asesmen otentik, disarankan agar diawali dengan tahapan eskplorasi pengetahuan awal. Eksplorasi pengetahuan awal tersebut penting untuk dilakukan dalam rangka mengemas rancangan pembelajaran yang lebih bermakna. Pengetahuan awal digunakan sebagai alternatif pijakan dalam merumuskan tujuan-tujuan pembelajaran.

2) Pada tahap grouping guru hendaknya menyiapakan fasilitas yang mendukung proses pembelajaran. Fasilitas belajar diupayakan agar dapat menggali respon-respon yang divergen dan memberi peluang kepada siswa melakukan seleksi, organisasi, dan integrasi pengalaman baru ke dalam pengetahuan yang telah dimiliki.

3) Sebagai mediator, guru hendaknya membangkitkan aktivitas belajar siswa agar pembelajaran PAIKEM dapat terwujud. Aktivitas kelas dapat dilakukan dengan memberikan praktikum ataupun demonstrasi yang diupayakan menggali kreativitas siswa.

4) Untuk mencapai prestasi belajar dan konsep diri secara mendalam pada pembelajaran sains, implementasi model pembelajaran kooperatif Group Investigation dengan asesmen otentik dianjurkan menggunakan masalah-masalah yang nyata, illdefined, dan ill-structured. Masalah-masalah tersebut dikemas dalam bentuk LKS.

5) Dalam model pembelajaran kooperatif Group Investigation dengan asesmen otentik dituntut untuk menggunakan laboratorium sebagai media penemuan bagi siswa. Guru hendaknya membimbing dan membantu 
siswa melakukan proses penemuan di laboratorium.

6) Kepala sekolah dan komite sekolah membantu pengadaan alat-alat dan media percobaan yang dapat digunakan untuk melakukan proses penemuan di dalam laboratorium.

7) Penelitian ini hanya sebatas mencari pengaruh model pembelajaran kooperatif Gl terhadap prestasi belajar dan konsep diri siswa, kepada rekanrekan diharapkan untuk melakukan penelitian pengembangan instrumen tentang penilaian otentik dan melaksanakan penilaian otentik dalam proses pembelajaran.

\section{DAFTAR RUJUKAN}

Agus Darmawan, I G., Sudhita, W. R, \& Wawan Sudatha, I G (2014). Pengaruh model pembelajaran kooperatiftipe group investigation terhadap hasil belajar siswa kelas $\mathrm{V}$ SD. Jurnal Mimbar PGSD Universitas Pendidikan Ganesha Jurusan PGSD. 2(1). Diakses 9 Juni 2015.

Arikunto, S. 2010. Prosedur penelitian. Jakarta: Rineka Cipta.
Bloom, B. S., Krathwohl, D R., \& Masia, B. B. 1990. Taxonomy of educational objektives: Book New York: David Mc Kay Company.

Brooks, W. D. 1989. Speech

Communication Sixth Edition. London: Brown Publishers

Cooley, C H. 2004. The Game of Science Education: Edidor by Jeffry Word. Boston New York San Fransisco Mikixo City Montreal Toronto London Madrid Munich Paris Hong Kong Sinagore Tokyo Cape Towe Sydeey, Allyn\& Bacon.

Haikal, H. 2002. Menyongsong Reformasi Pendidikan. Jurnal Pendidikan dan Kebudayaan. No.035. Maret 2002.

Santyasa, I W. 2012. Pembelajaran inovatif. Singaraja: Universitas Pendidikan Ganesha.

Santyasa, I W. 2014. Asesmen dan evaluasi pembelajaran fisika. Singaraja: Graha IImu

Suastra, I W. 2009. Pembelajaran sains terkini. Singaraja: Universitas Pendidika Ganesha.

Suparno, P. 2001. Teori perkembangan kognitif Jean Piaget. Yogyakarta: Kanisius.

Syamsir. 2003. Model penilaian dalam pendidikan civics: Refleksi Pengalaman dari SekolahSekolah Menengah di Indiana, USA. Jurnal Pendidikan dan Kebudayaan. 2(63):26-32.

Trianto.2007. Model-model 
Jurnal Teknologi Pembelajaran Indonesia

ISSN: 2615-2797(Print) | ISSN: 2614-2015 (Online)

Volume 8 Nomor 2 Tahun 2018

Pembelajaran inovatif

berorientasi

Konstruktivistik.Jakarta:Prestasi

Pustaka. 